\title{
Velocity structure and the role of fluids in the West Bohemia Seismic Zone
}

\author{
C. Alexandrakis ${ }^{1}$, M. Calò ${ }^{2}$, F. Bouchaala ${ }^{3}$, and V. Vavryčuk ${ }^{4}$ \\ ${ }^{1}$ Institute of Geophysics and Geoinformatics, TU Bergakademie Freiberg, Freiberg, Germany \\ ${ }^{2}$ Berkeley Seismological Laboratory, Berkeley, USA \\ ${ }^{3}$ The Petroleum Institute, Abu Dhabi, United Arabic Emirates \\ ${ }^{4}$ Institute of Geophysics, Czech Academy of Science, Prague, Czech Republic
}

Correspondence to: C. Alexandrakis (catherine.alexandrakis@geophysik.tu-freiberg.de)

Received: 27 January 2014 - Published in Solid Earth Discuss.: 11 February 2014

Revised: 14 July 2014 - Accepted: 15 July 2014 - Published: 27 August 2014

\begin{abstract}
In this study, we apply the double-difference tomography to investigate the detailed 3-D structure within and around the Nový Kostel Seismic Zone, an area in the Czech Republic known for frequent occurrences of earthquake swarms. We use data from the 2008 swarm since it has already been analysed in terms of earthquake focal mechanisms, principal faults, tectonic stress and foci migration. We selected about 500 microearthquakes recorded at 22 local seismic stations of the West Bohemia seismic monitoring network (WEBNET). Applying double-difference tomography, combined with weighted average model (WAM) post-processing to correct for parameter dependence effects, we produce and interpret 3-D models of the Vp-to-Vs ratio $(\mathrm{Vp} / \mathrm{Vs})$ in and around the focal zone. The modelled $\mathrm{Vp} / \mathrm{Vs}$ ratio shows several distinct structures, namely an area of high $\mathrm{Vp} / \mathrm{Vs}$ ratio correlating with the foci of the microearthquakes, and a layer of low values directly above it. These structures may reflect changes in lithology and/or fluid concentration. The overlaying low Vp/Vs ratio layer coincides with the base of the Fichtelgebirge (Smrčiny) granitic intrusion. It is possible that the base of the layer acts as a fluid trap and an upper limit to the seismicity, resulting in observed periodic swarms.
\end{abstract}

\section{Introduction}

The Nový Kostel Seismic Zone is the most seismically active area in West Bohemia (Czech Republic), a region known for frequent earthquake swarms (Fig. 1). Isotope analysis (mainly $\mathrm{He} 3 / \mathrm{He} 4$ ) indicates that the fluids released from gas vents and springs within and around the Cheb Basin are magmatic in nature (Bräuer et al., 2005; Weise et al., 2001). This has led to the hypothesis that migrating fluids play a major role in the swarm activity (Bräuer et al., 2005; Geissler et al., 2005; Hainzl et al., 2012; Špičák and Horálek, 2001).

Seismic swarms in the Nový Kostel area occur at the junction of the Mariánské-Lázně Fault and the Počátky-Plesná Fault Zone (Bankwitz et al., 2003; Peterek et al., 2011; Fischer et al., 2014). The 2008 swarm had two dominant focal mechanisms with principal fault planes oriented at $169^{\circ}$ and $304^{\circ}$ (Vavryčuk, 2011). The $169^{\circ}$ principal fault corresponds well to the Počátky-Plesná Fault segments in the Nový Kostel Zone (Bankwitz et al., 2003), and the $304^{\circ}$ principal fault is approximately parallel to the Gera-Jáchymov Fault Zone (Švancara et al., 2008). The 2008 swarm shows many similarities to swarms which occurred in 1985-1986 and 2000. These three swarms all activated the same fault planes and the foci occurred in the same depth range (Fischer et al., 2010, 2014). Also, the focal mechanisms were similar. However, the magnitudes of the strongest events were different: 4.6, 3.4 and 3.8 for the 1985-1986, 2000 and 2008 swarms, respectively. As with most of the Nový Kostel earthquake swarms, the 2008 swarm displayed an upward migration pattern, meaning that the hypocentres occurred at progressively shallower depths over the course of the swarm (Fischer et al., 2010).

Several studies have produced models of the crustal structure using a variety of geophysical methods and data (e.g. Hrubcová et al., 2005, 2013; Málek et al., 2001; Mlčoch and 


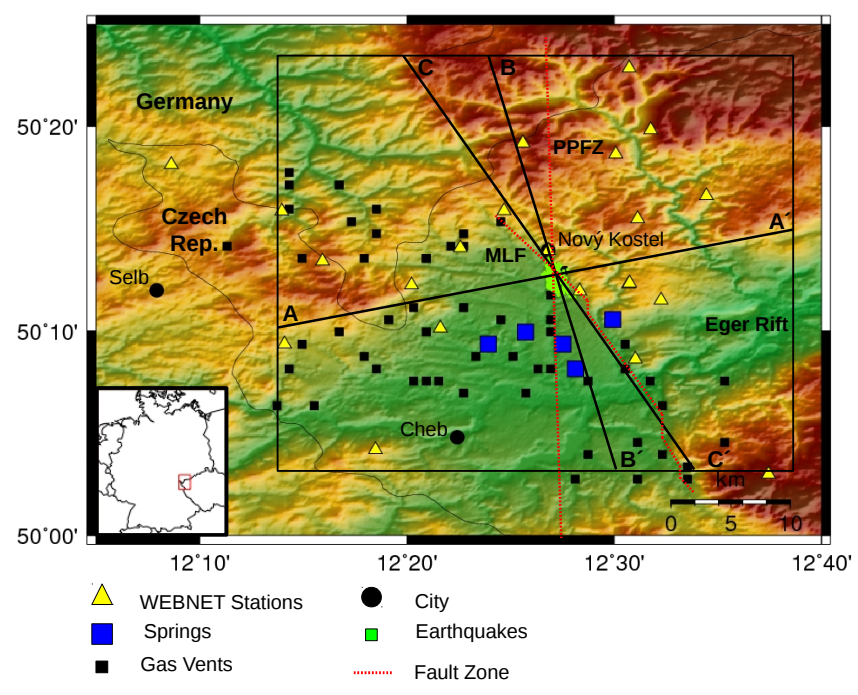

Figure 1. Topographic map showing the Nový Kostel Seismic Zone. Inset shows location within Europe. Black box shows inversion area and lines $\mathrm{A}-\mathrm{A}^{\prime}, \mathrm{B}-\mathrm{B}^{\prime}$ and $\mathrm{C}-\mathrm{C}^{\prime}$ note profiles shown in other figures. Abbreviations: MLF - Mariánské-Lázně Fault Zone, PPFZ Počátky-Plesná Fault Zone. Mineral spring and gas vent locations digitized from Heinicke et al. (2009).

Skácelová, 2009; Růžek et al., 2007; Tomek et al., 1997). Most of these studies were aimed at investigating the deeper parts of the crust or the crust on the regional scale and therefore did not resolve the focal zone structures. In this study, double-difference tomography is used to investigate the velocity structure in the focal zone. It is able to image small-scale velocity heterogeneities near a focal zone which contains numerous closely-spaced earthquakes recorded at seismic stations with good azimuthal coverage (Zhang and Thurber, 2003). These conditions are met by the clustered nature of the swarm and the West Bohemia seismic monitoring network (WEBNET).

As with other seismic tomography methods, the starting model and inversion parameters may lead to artefacts (Kissling et al., 1994). Checkerboard and other synthetic tests are often used to determine the model resolution. However, it is difficult to deduce which features are artefacts of the parameterization. To address this problem, the weighted average model (WAM) method is applied to the 2008 swarm data set (Calò et al., 2011). In this method, a suite of tomography models is calculated using a variety of reasonable input parameters, such as the starting velocity model and inversion parameterization. These models are averaged together, using a weighting factor defined by each model's Derivative Weight Sum (weighted hit count; Toomey and Foulger, 1989). This process reduces bias and artefacts introduced by the a priori parametrization. Finally, extensive synthetic and resolution tests are used to confirm if the imaged velocity perturbations are resolved structures or artefacts.
Analysis of the model focuses on the rupture zone and the area directly above it. Structures observed in the Vp-to-Vs ratio $(\mathrm{Vp} / \mathrm{Vs})$ model are assessed in terms of local geology and the potential role of fluids in the swarm cycle.

\section{Data}

In this study, we use earthquakes that occurred during the 2008 Nový Kostel earthquake swarm (Fischer et al., 2010). This swarm had the fastest $(\sim 4$ weeks) and largest total seismic moment $\left(4 \times 10^{16} \mathrm{Nm}\right)$ released in over 20 years (Fischer et al., 2010). About 25000 earthquakes with local magnitude greater than -0.5 were recorded by 23 WEBNET seismic stations (Fig. 1) and located using the program FASTHYPO (Herrmann, 1979). The epicenters form an elongated cluster ( $\sim 4 \mathrm{~km}$ long) and hypocentres ranged between 7 and $11 \mathrm{~km}$ depth (Fischer et al., 2010). Bouchaala et al. (2013) used manually-picked $P$-wave and $S$-wave arrival times and waveform cross-correlated times to relocate 483 selected events using HypoDD, a double-difference hypocentre location program (Waldhauser and Ellsworth, 2000). The events were selected to lie in a broad magnitude range and the foci to cover the entire active area. The picked arrival times had an error of $\pm 4 \mathrm{~ms}$ for the $P$ waves and $\pm 10 \mathrm{~ms}$ for the $S$ waves, and only waveform cross-correlated times with a correlation coefficient of at least 0.8 were used. The HypoDD-relocated events are more clustered and clearly define the fault plane (Bouchaala et al., 2013). The new locations differ from the FASTHYPO locations by a maximum of $1140 \mathrm{~m}$ in east-west, $880 \mathrm{~m}$ in north-south and $560 \mathrm{~m}$ in depth. Overall, the relocated data has an average location error of $17 \mathrm{~m}$ and an average RMS of $4.8 \mathrm{~ms}$ (Bouchaala et al., 2013). In this study, we select 473 events from the Bouchaala et al. (2013) data set for the $P$-wave and $S$-wave velocity model tomography inversion. Over $8500 P$-wave and $S$-wave arrivals were manually picked, resulting in $73028 P$-wave and $72967 S$-wave differential times and $63656 P$-wave and $59069 S$-wave cross-correlated times.

\section{Methodology}

\subsection{Double-difference tomography}

Double-difference tomography is an adaptation of local earthquake tomography (LET). Typically, LET is used to characterize structures between the source locations and the receivers. This method is most effective when the events are widely spread. Double-difference tomography is ideal for regions where the events are clustered closely together and can image the velocity structures immediately surrounding the cluster (Zhang and Thurber, 2003). This method is termed a "double-difference" tomography because the algorithm minimizes the modelled and observed travel time difference between two earthquakes recorded at a single station. As a con- 

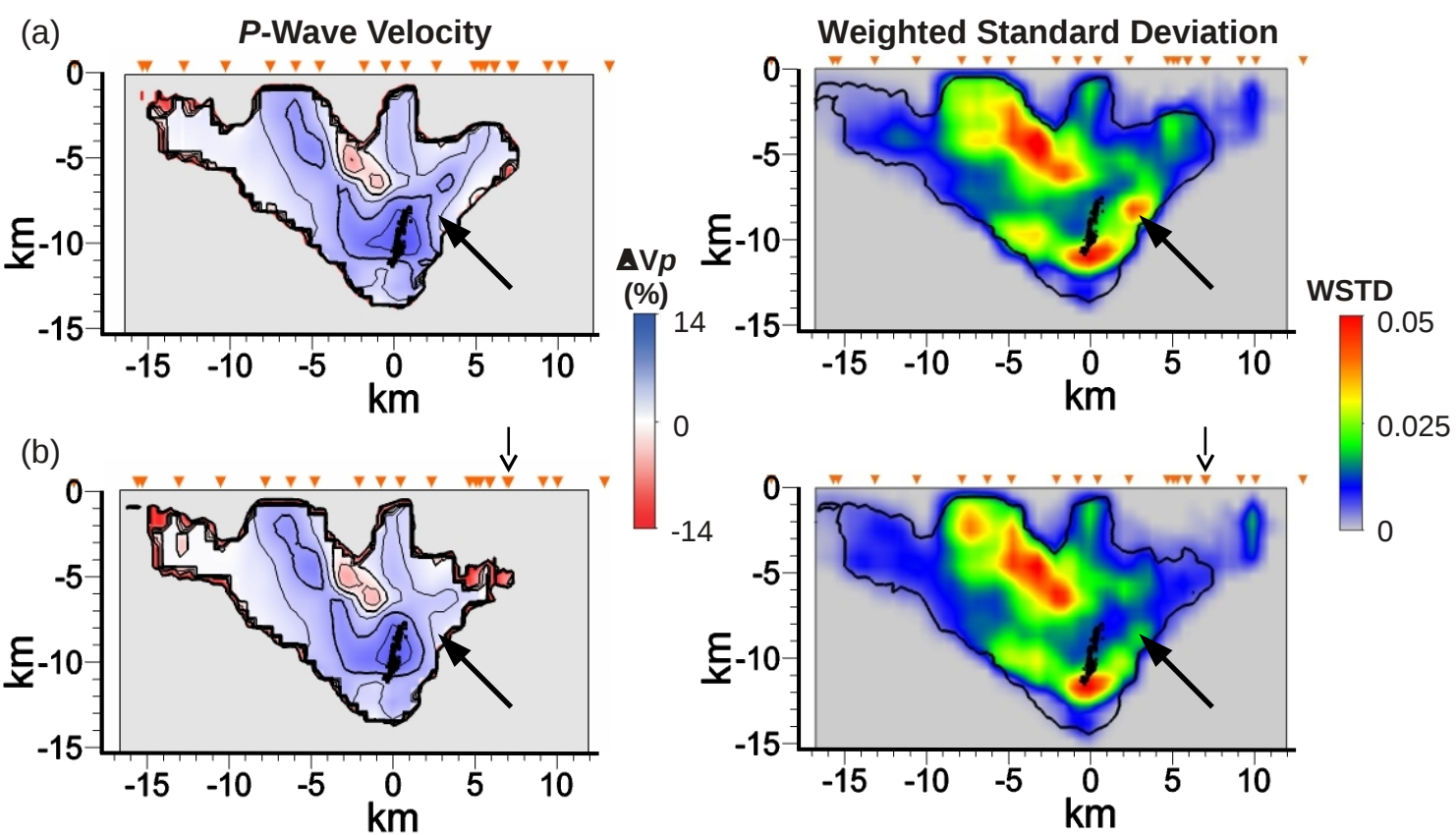

Figure 2. $P$-wave weighted average model (WAM) and weighted standard deviation (WSTD) for profile A-A $\mathrm{A}^{\prime}$ for (a) all stations and (b) selected stations. Bold arrow indicates the region of high WSTD present when all stations are used, and suppressed when the problematic station (indicated in $\mathbf{b}$ ) is removed from the data set. Only areas constrained by the data are shown. $P$-wave velocities are shown as percentage difference from the regional model of Málek et al. (2001).

sequence, any influence from velocity anomalies or heterogeneities near the stations is suppressed due to the converging raypaths. Detailed knowledge of the near-surface geology is not required, but no shallow structures are determined. We use the program TomoDD (Zhang and Thurber, 2003) to jointly invert both $P$-wave and $S$-wave velocity models and hypocentre parameters. The $P$ and $S$ travel time catalogues are of comparable quality, size and raypath coverage (Supplement Fig. S1), allowing for the determination of the $P$ wave to $S$-wave velocity ratio (Vp/Vs) calculated by direct division of the $P$-wave and $S$-wave velocity models.

The basic model for this study is the regional gradient $P$ wave velocity model of Málek et al. (2001) with a uniform Vp / Vs of 1.70 (Fig. 6). In the shallow part of the model (down to $4 \mathrm{~km}$ ), layer thicknesses vary in order to maintain the velocity gradient. Below $4 \mathrm{~km}$, the model is defined in $1 \mathrm{~km}$ thick layers. The surface datum coincides with station NKC's elevation (609.94 $\mathrm{m}$ above sea level) and is centered at the swarm centroid $\left(50.2105^{\circ} \mathrm{N}\right.$ and $\left.12.4508^{\circ} \mathrm{E}\right)$.

To reduce bias from the starting earthquake locations, both the FASTHYPO- and the HypoDD-located data sets are used in the WAM calculation.

\subsection{Weighted average model analysis}

As with many tomography algorithms, artefacts and model bias associated with the starting parametrization are difficult to quantify. The WAM method reduces the influence of the starting parametrization (Calò et al., 2011, 2012). In order to apply the WAM method, the basic seismic wave velocity model is defined on a 3 -D Cartesian grid. The model parametrization was then perturbed by shifting the nodes, changing node spacing and rotating the grid. Slightly faster and slower $P$-wave velocity models were also used by shifting the velocities in depth by $\pm 300 \mathrm{~m}$. In total, 12 unique starting velocity model parameterizations were defined and applied to the FASTHYPO and HypoDD-located data sets (Supplement Fig. S2). The resulting 24 models were then used in the WAM calculation. We also calculated the weighted standard deviation (WSTD) for both the $P$ - and $S$ wave velocity WAMs. The WSTD can indicate the stability of structures within the model. A high WSTD indicates that the velocity field calculated at that location depends on the starting parametrization and could therefore be affected by artefacts.

\section{Model resolution and synthetic tests}

A first analysis of the velocity models and WAM showed a region with anomalously high $P$-wave velocities to the east of the focal zone, which also corresponds to an area of high WSTD (Fig. 2a). This region has $P$-wave velocities more than $15 \%$ greater than the regional model. Further examination showed that it correlates to the raypath volume between the hypocentres and a single station. Synthetic tests con- 
firmed that local changes in the surface geology would not produce such an anomaly (Supplement Fig. S3). To test if the anomaly was indeed related to the single station, the WAM analysis was repeated, having removed the data from this station, resulting in reduced WSTD (Fig. 2b). When other stations were removed, the resulting models all contained the same high WSTD region as the WAM calculated with all of the stations included. Based on these tests, the raw data from this station were investigated and an error in the onset time was found (A. Boušková, personal communication, 2012). Therefore, data from this station are excluded from the remaining tests and interpretations.

In order to further assess the model resolution, a series of synthetic and resolution tests were conducted. The first test assesses the dependence of the calculated models on the starting velocity model. This was accomplished by running the tomography with four perturbations of the starting model. The first two models were uniformly $0.5 \mathrm{~km} \mathrm{~s}^{-1}$ faster or slower than the regional model (Supplement Fig. S4). The $\mathrm{Vp} / \mathrm{Vs}$ was not changed (i.e. $\mathrm{Vp} / \mathrm{Vs}=1.7$ ), meaning both $P$-wave and $S$-wave velocities were perturbed. In the last two models, the regional model's $P$-wave velocity was unchanged, but the $S$-wave velocities were perturbed by increasing or decreasing the $\mathrm{Vp} / \mathrm{Vs}$ ratio by 0.05 (Supplement Fig. S4). The resulting models show that the calculated $P$-wave velocity is influenced by the starting model. However, the Vp / Vs models all show similar structures and values below $5 \mathrm{~km}$, regardless of the starting model (Supplement Fig. S4). This indicates that the resultant Vp/Vs model is stable and independent of the starting model.

The next set of tests investigates whether isolated velocity perturbations are recovered. This test is motivated by strong velocity and $\mathrm{Vp} / \mathrm{Vs}$ perturbations observed along the fault plane and directly above the focal zone (see Sect. 5 for details). In the first four models (Fig. 3), a block mimicking the fault plane is perturbed. This block is $3 \mathrm{~km}$ wide in the $x$ direction, $6 \mathrm{~km}$ wide in the $y$ direction, $5 \mathrm{~km}$ deep, and all earthquakes lie in this block. Two models have the $P$-wave velocities within the block perturbed by $\pm 5 \%$ $(\mathrm{Vp} / \mathrm{Vs}=1.7)$ (Fig. 3a). In the next two models, the Vp / Vs ratio is perturbed by $\pm 5 \%$ within the block (Fig. 3c). All velocities and ratios outside the block correspond to the regional model of Málek et al. (2001). $P$ and $S$ synthetic travel times were calculated for the synthetic models using the WEBNET earthquake locations and the pseudo-bending ray tracing algorithm (Um and Thurber, 1987) that tomoDD uses to calculate the travel times (Zhang and Thurber, 2003). In these tests, the synthetic data are limited to $P$ and $S$ catalogue times and do not include a cross-correlation times. Therefore, these tests represent a "worst case" result.

The models show very good recovery in both shape and magnitude for the $\mathrm{Vp} / \mathrm{Vs}$ ratios. The models with only $P$ wave velocity perturbation have well-restored $P$-wave velocities and Vp/Vs models (Fig. 3b). However, for the models with $\mathrm{Vp} / \mathrm{Vs}$ perturbations, it is evident that the recovered $P$ - wave velocities are strongly influenced (Fig. 3d). This indicates that the recovered anomalous $P$-wave velocities might be artefacts if areas display high or low Vp/Vs. However, the $\mathrm{Vp} / \mathrm{Vs}$ ratio itself is properly resolved and can be considered robust.

In the next test, we add a $2 \mathrm{~km}$ thick contrasting layer above the blocks (Supplement Fig. S5). For example, in the model with high $P$-wave velocity along the fault plane, the velocities in the overlaying $2 \mathrm{~km}$ are decreased by $5 \%$ (Supplement Fig. S5a), and in the model with the low Vp / Vs ratio block, the overlaying $2 \mathrm{~km}$ have a $5 \%$ higher $\mathrm{Vp} / \mathrm{Vs}$ ratio (Supplement Fig. S5c). As above, $P$ and $S$ synthetic travel times for each of the synthetic models were calculated using the WEBNET earthquake locations and no cross-correlated times are used.

As with the previous test, the recovered models show that the $P$-wave velocities are influenced by the $\mathrm{Vp} / \mathrm{Vs}$ ratio (Supplement Fig. S5b and d). The influence of $P$-wave velocity changes on the $\mathrm{Vp} / \mathrm{Vs}$ ratio is minor. These tests show that some structures observed in the $P$-wave velocity model may be linked to changes in the $\mathrm{Vp} / \mathrm{Vs}$ ratio. The calculated $\mathrm{Vp} / \mathrm{Vs}$ models resolve structures directly above the focal zone very well. These models are more reliable and can be interpreted without consideration of $P$-wave velocity perturbations.

As a final test, we conduct a classical checkerboard for each model perturbation used in the WAM, and we then calculate a checkerboard WAM. The regional model is used to create a checkerboard model with the $P$-wave velocities alternating $\pm 5 \%$ within the layers. The $\mathrm{Vp} / \mathrm{Vs}$ is kept constant at 1.7. The checkerboard cell sizes are two horizontal nodes wide and one vertical node deep. Consequently, the cell volumes are not constant throughout the model. Within the focal zone, the cells cover a $4 \mathrm{~km}^{2}$ area and are $1 \mathrm{~km}$ deep (Fig. 4a). Synthetic $P$ and $S$ travel times were calculated from the WEBNET earthquake locations. Randomly distributed errors $( \pm 0.01 \mathrm{~s}$ for $P$ times and $\pm 0.02 \mathrm{~s}$ for $S$ times) were added to the synthetic times. As with the previous synthetic tests, no synthetic cross-correlated times are used. The checkerboard WAM is calculated using the same model parameterizations as for the observed data WAM. The resulting model (Fig. 4b) is well resolved within the focal zone. As expected, velocities near the surface (top $5 \mathrm{~km}$ ) are not resolved.

A comparison of the checkerboard WAM with the WSTD values obtained from the observed data (Fig. 4c) shows that the well resolved focal zone corresponds to low experimental WSTD (WSTD $<0.02 \mathrm{~km} \mathrm{~s}^{-1}$ ). Regions with high WSTD show smearing and poor resolution in the checkerboard WAM. The maximum WSTD is less than $0.03 \mathrm{~km} \mathrm{~s}^{-1}$ in the focal zone is less and $0.05 \mathrm{~km} \mathrm{~s}^{-1}$ outside of the focal zone. These maximum values are significantly lower than velocity variations observed in the focal zone. Even considering an error bar of $2 \sigma(\sim 95 \%$ confidence interval $)$, the reliability of the anomalies remains very high. Furthermore, there is 
(a)
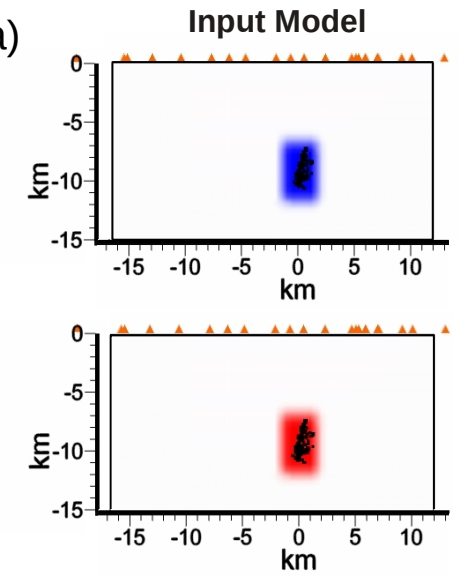

(c)

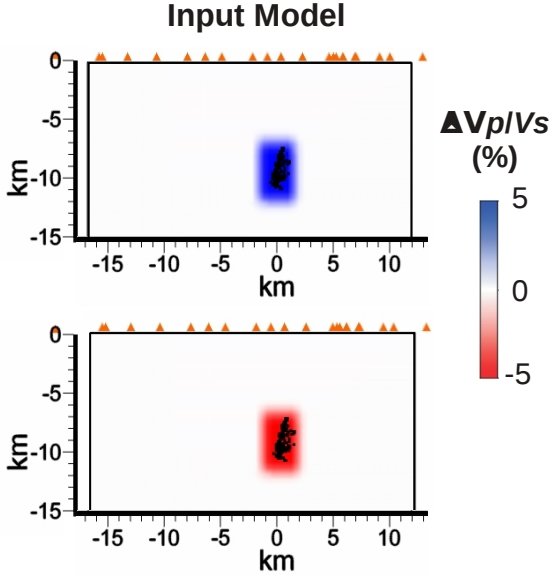

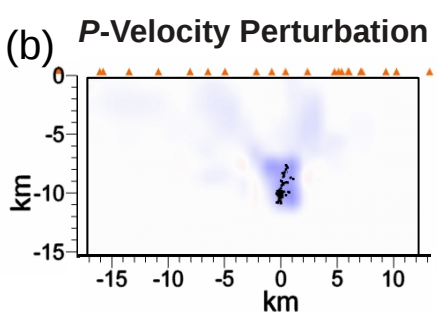
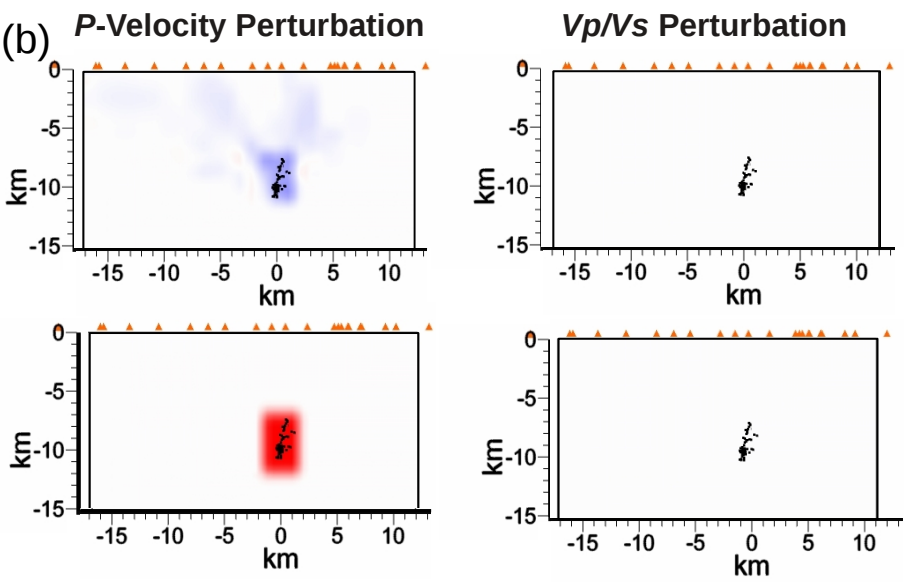

(d)
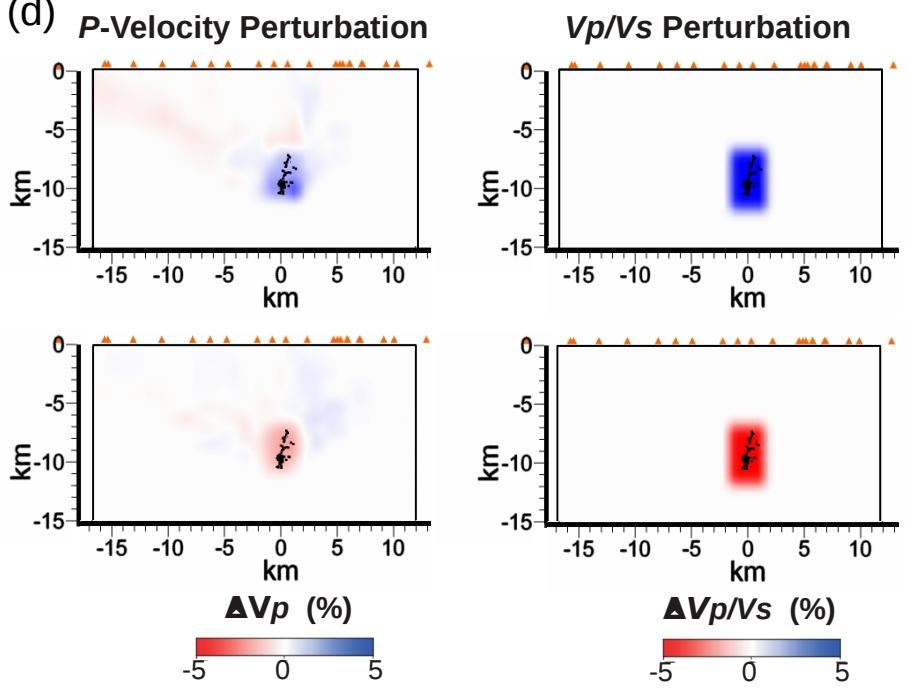

Figure 3. Anomaly restoration synthetic test. A block $3 \mathrm{~km}$ wide in the $x$ direction, $6 \mathrm{~km}$ wide in the $y$ direction, $5 \mathrm{~km}$ deep and enclosing all earthquakes is perturbed. Within the block, (a) $P$ wave velocities are modified by $\pm 5 \%$ or (c) Vp / Vs ratio is perturbed by $\pm 5 \%$. All velocities and ratios outside the block correspond to the regional model of Málek et al. (2001). The recovered models - (b) and (d) - all show that the $\mathrm{Vp} / \mathrm{Vs}$ is well recovered. The recovered $P$-wave velocity models show some smearing and are also influenced by fluctuation in the $\mathrm{Vp} / \mathrm{Vs}$ ratio.

no spatial correlation between the highest WSTDs and significant velocity anomalies indicating a low dependence on the initial parameters. Since the focus of the discussion is on the $\mathrm{Vp} / \mathrm{Vs}$ model, the interpretation will be constrained to regions where the observed WSTD values for both the $P$ and $S$ model are $0.02 \mathrm{~km} \mathrm{~s}^{-1}$ or less.

\section{Results and interpretation}

In crustal rocks, compressional and shear wave velocities (and thus Vp / Vs) are dependent on several factors, such as composition, temperature, pressure, microcrack density, pore pressure and fracture density. The Vp / Vs has been used as an indicator of fluids within many earthquake settings, such as subduction zones (Husen and Kissling, 2001; Calò et al., 2012), shear zones (McLaren et al., 2008), collision zones
(Scarfi et al., 2007), volcanoes (Agostinetti and Chiarabba, 2008) and hydrocarbon exploration (Zhang et al., 2009). Several studies have indicated that fluids may also play a role in the periodic swarms in Nový Kostel (Bräuer et al., 2005; Geissler et al., 2005; Heinicke et al., 2009; Hainzl et al., 2012; Špičák and Horálek, 2001).

There are two main structures in the Vp/Vs WAM: the high $\mathrm{Vp} / \mathrm{Vs}$ concentrated along the fault plane and the low $\mathrm{Vp} / \mathrm{Vs}$ layer directly above the focal zone (Fig. 5). The Nový Kostel focal zone has a mean Vp/Vs ratio of $1.73 \pm 0.04$, indicating a clear increase from the regional value of 1.70 (Málek et al., 2001). These high values are concentrated around the relocated hypocentres, which also correlate with the $169^{\circ}$ principal fault (Vavryčuk, 2011). The base of the overlaying layer with low $\mathrm{Vp}$ / Vs corresponds to the depth of the shallowest relocated earthquakes. This over- 
(a)
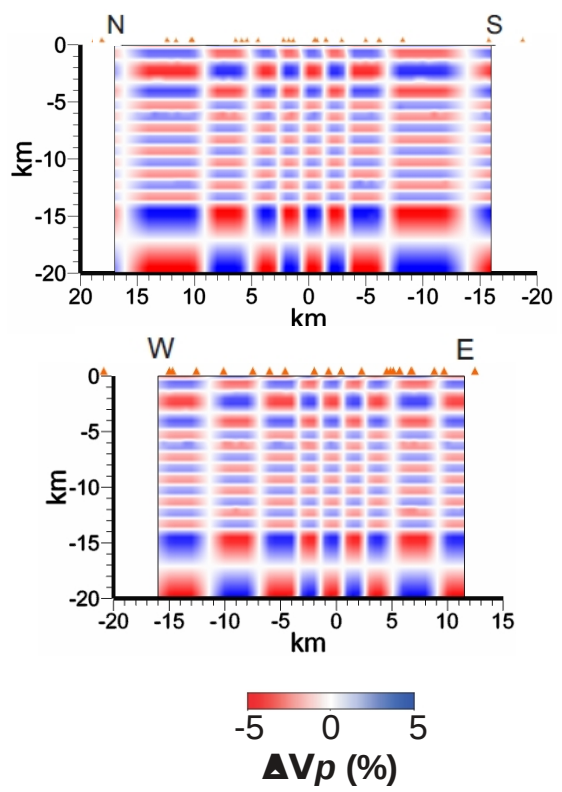

(b)
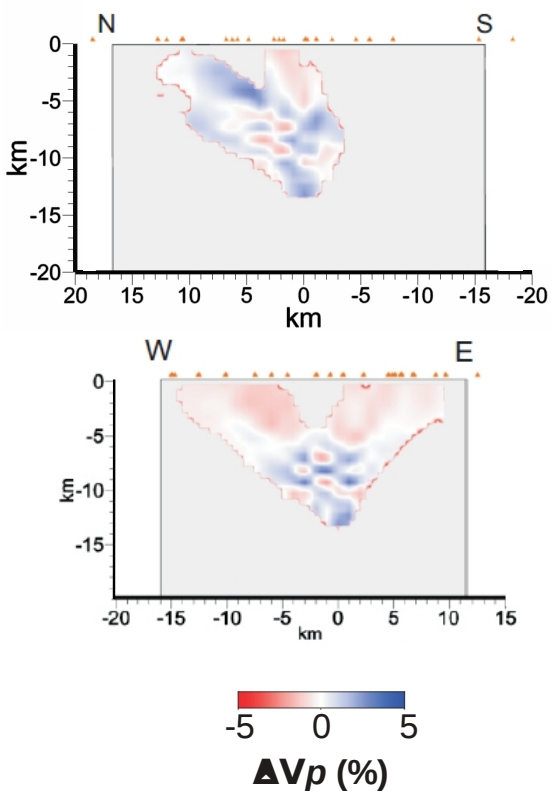

(c)
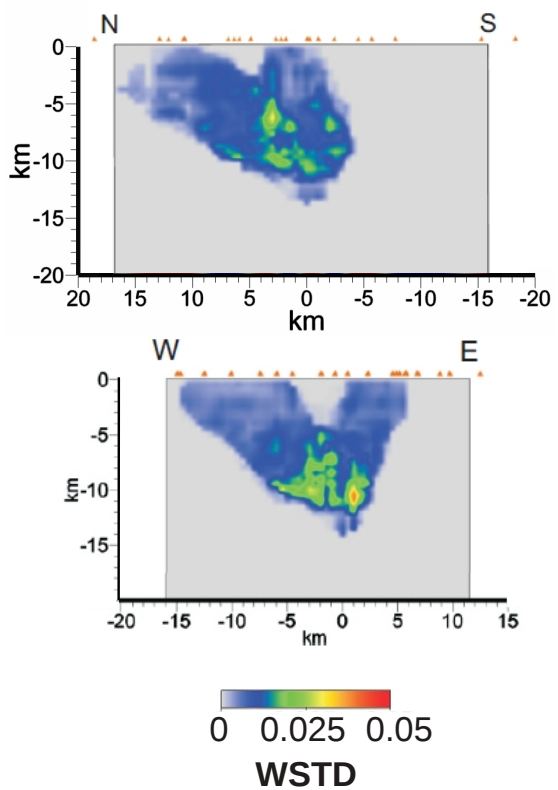

Figure 4. Checkerboard resolution test. North-south and east-west profiles (top and bottom, respectively) showing (a) the starting checkerboard model with a $\pm 5 \%$ variation in $P$-wave velocity, (b) the recovered weighted average model (WAM) and (c) the weighted standard deviation (WSTD) from the observed data. Shallow areas (depth less than $5 \mathrm{~km}$ ) are not resolved. Within the focal zone, areas with poor checkerboard resolution coincide with WSTD values greater than $0.03 \mathrm{~km} \mathrm{~s}^{-1}$. Only areas constrained by the data are shown.

(a)

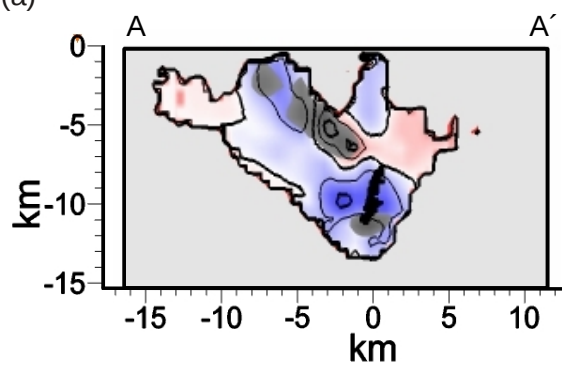

(c)

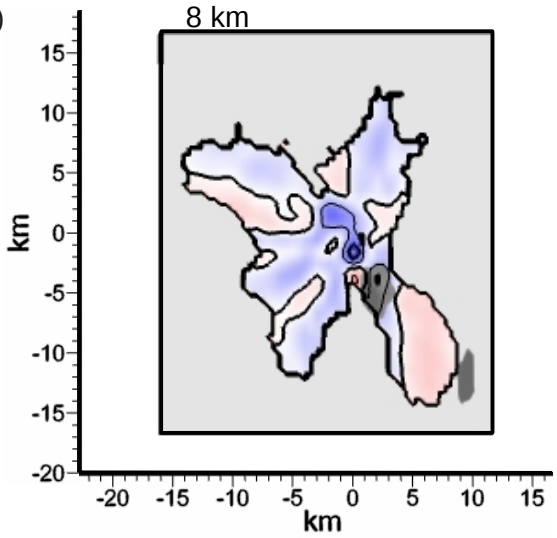

(b)

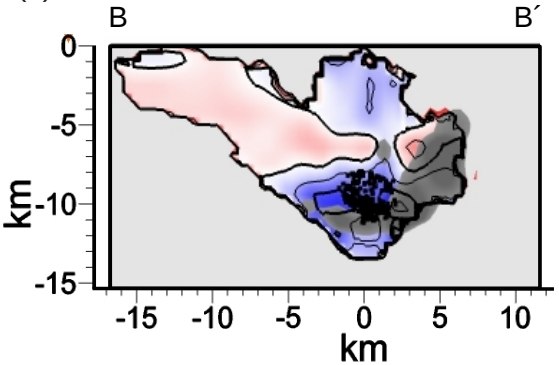

(d)

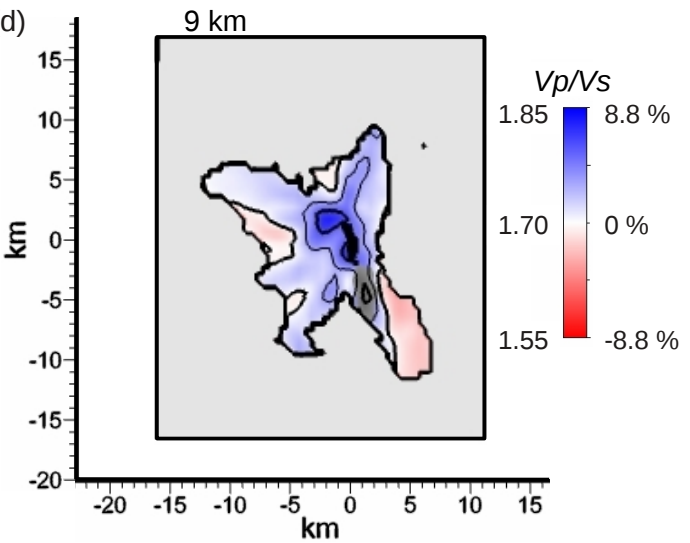

Figure 5. Vp / Vs ratio weighted average model. In the across-strike (a) and along-strike (b) profiles, the focal zone is characterized by high $\mathrm{Vp} / \mathrm{Vs}$ values. Depth slices through the hypocentres at $8 \mathrm{~km}$ (c) and $9 \mathrm{~km}(\mathbf{d})$ show that these higher values concentrate along the fault plane. An almost-continuous layer of low Vp / Vs overlays the hypocentres between 5 and $7 \mathrm{~km}$. Grey mask shows areas with WSTD greater than $0.03 \mathrm{~km} \mathrm{~s}^{-1}$. Only areas constrained by the data are shown. Earthquake hypocentres are projected onto the profiles and depth slices. 
Table 1. Average seismic velocities within the Nový Kostel focal zone calculated from the weighted average model (WAM).

\begin{tabular}{rrrr}
\hline Depth & $\begin{array}{r}\text { Mean } P \text {-wave } \\
\text { velocity } \\
\left(\mathrm{km} \mathrm{s}^{-1}\right)\end{array}$ & $\begin{array}{r}\text { Mean } S \text {-wave } \\
\text { velocity } \\
\left(\mathrm{km} \mathrm{s}^{-1}\right)\end{array}$ & $\begin{array}{r}\text { Mean } \\
\mathrm{Vp} / \mathrm{Vs} \\
\text { ratio }\end{array}$ \\
\hline 5 & 6.10 & 3.58 & 1.70 \\
5.5 & 6.19 & 3.64 & 1.70 \\
6 & 6.28 & 3.71 & 1.69 \\
6.5 & 6.37 & 3.76 & 1.69 \\
7 & 6.46 & 3.80 & 1.70 \\
7.5 & 6.55 & 3.83 & 1.71 \\
8 & 6.62 & 3.84 & 1.73 \\
8.5 & 6.69 & 3.85 & 1.74 \\
9 & 6.77 & 3.87 & 1.75 \\
9.5 & 6.86 & 3.90 & 1.76 \\
10 & 6.94 & 3.94 & 1.76 \\
\hline
\end{tabular}

laying layer $(\sim 5-7 \mathrm{~km})$ has a mean $\mathrm{Vp} / \mathrm{Vs}$ ratio value of $1.70 \pm 0.03$. These structures are interpreted in terms of local geology and the potential role of fluids in the Nový Kostel Seismic Zone. For comparison, the $P$-wave and $S$-wave velocity WAM is shown in Supplement Fig. S6.

First, we look at the average values within the focal zone (Fig. 6 and Table 1). This is calculated over a lateral extent of $\pm 4 \mathrm{~km}$ in $x$ and $y$ and $0.5 \mathrm{~km}$ depth intervals. As was also seen in the profiles (Fig. 5), the transition between the layer exhibiting low $\mathrm{Vp} / \mathrm{Vs}$ ratio and the focal zone featuring high $\mathrm{Vp} / \mathrm{Vs}$ ratio values occurs at a depth of $7 \mathrm{~km}$. Within the fault zone (7-10 km depth) and overlaying layer (5-7 km depth), the mean $\mathrm{Vp} / \mathrm{Vs}$ ratio is $1.73 \pm 0.04$ and $1.70 \pm 0.03$, respectively. The range of $\mathrm{Vp} / \mathrm{Vs}$ values within the fault zone and overlaying layer are all in the documented range for igneous and metamorphic rocks, including granites and gneisses (Gercek, 2007). These ratio values are consistent with measurements of granite, gneiss and schist at $200 \mathrm{MPa}$. The higher ratios within the focal zone also correlate with phyllite measurements at $200 \mathrm{MPa}$ (Christensen, 1996).

Studies of wet and dry granitic and gneissic samples have shown that the $P$-wave velocity increases with saturation (Kahraman, 2007). This has also been shown for saturated rocks under overpressured conditions (Ito et al., 1979; Popp and Kern, 1994). Even if the calculated velocity model values are dependent on the starting model, the average $P$-wave velocity gradient increases with depth and a distinct decrease in average $S$-wave velocity occurs at $7 \mathrm{~km}$. The resulting high $\mathrm{Vp} / \mathrm{Vs}$ ratio values observed along the fault plane may indicate that the rupture area consists of fluid-filled, fractured rock under overpressured conditions, which can be caused by fluids or their migration in the presence of a structural barrier. This is consistent with previous results showing overpressured conditions during the 2008 swarm (Hainzl et al., 2012). In addition, moment tensor analysis of swarm earthquakes
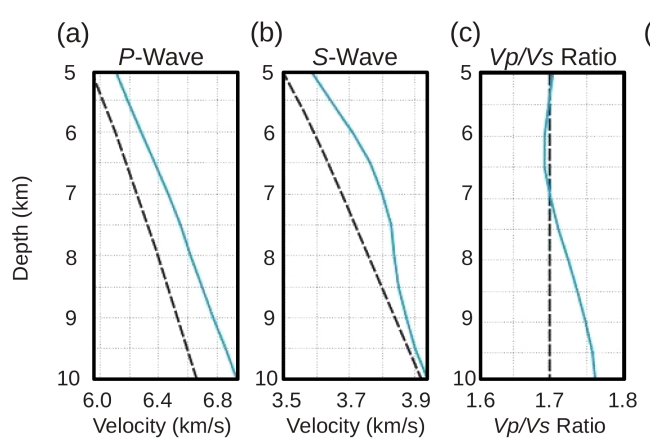

(d) Earthquake Distribution

Figure 6. Average $P$-wave velocities (a), $S$-wave velocities (b), and $\mathrm{Vp} / \mathrm{Vs}$ ratio values (c) within the focal zone. The average WAM values (solid lines) are calculated for all resolved nodes within $\pm 4 \mathrm{~km}$ from the grid origin and in $0.5 \mathrm{~km}$ thick layers. The distribution of earthquake source in depth (d) is also shown. Please note the different depth scale in (d). Dashed lines indicate the regional model from Málek et al. (2001).

has indicated tensile fracturing during the 1997 and 2008 swarms (Vavryčuk, 2002; Vavryčuk et al., 2013). This type of fracturing may relate to high pore fluid pressure (Vavryčuk, 2002). The area of high Vp / Vs values does not extend past the shallowest hypocentre, indicating that any fractures and fluids are limited to the rupture zone (Fig. 6d).

Beneath the Cheb Basin, the shallow and mid-crust geology is dominated by the Fichtelgebirge (Smrčiny) granitic complex (Hecht et al., 1997). The geological structures underlying the Nový Kostel Seismic Zone are derived mainly from surface geology, gravity modelling (Hecht et al., 1997; Nehybka and Skácelová, 1997) and the 9HR/91 reflection seismic survey (Tomek et al., 1997). Gravity studies have shown that the Fichtelgebirge granitic complex correlates to a large, low-gravity anomaly which extends down to a depth of at least $6 \mathrm{~km}$ beneath Nový Kostel, and has its root along the Mariánské-Lázně Fault (Hecht et al., 1997). Throughout the rest of the basin, the granitic complex is thin and has its base at $2-3 \mathrm{~km}$. Nový Kostel is located less than $2 \mathrm{~km}$ from the northern edge of the granitic complex, so the base decreases very rapidly from a depth of $\sim 6$ to $\sim 2 \mathrm{~km}$ (Hecht et al., 1997). The remaining upper crust is composed of various granites, metasediments and metabasites (Fig. 7; Hecht et al., 1997; Nehybka and Skácelová, 1997).

In Fig. 7, the structures observed in the Vp / Vs WAM are compared to a model derived from the $9 \mathrm{HR} / 91$ seismic profile and gravity modelling (Nehybka and Skácelová, 1997; Tomek et al., 1997). The most prominent feature in this profile is the region of low $\mathrm{Vp} / \mathrm{Vs}$, directly above the focal zone (between 5 and $7 \mathrm{~km}$ deep). The transition from low to high $\mathrm{Vp} / \mathrm{Vs}$ (with respect to the regional value of 1.70) correlates with the base of the Fichtelgebirge granitic complex in this area (Hecht et al., 1997). Also, when the earthquake foci are projected onto the geological section from Weise et al. (2001), as shown in Fig. 7, they concentrate within the 


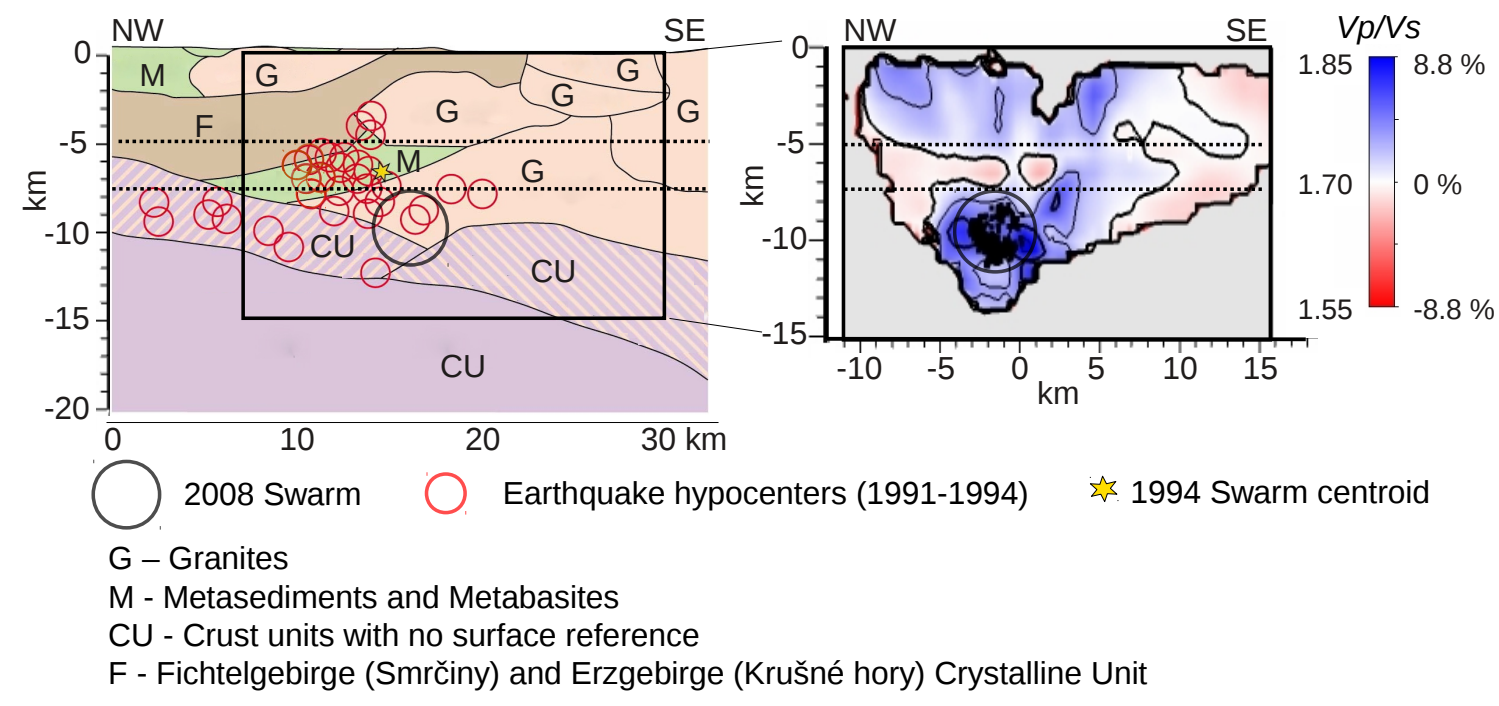

Figure 7. Comparison between a geological interpretation of the Nový Kostel Seismic Zone (left), based on the 9HR/91 seismic profile and gravity modelling (Nehybka and Skácelová, 1997; Tomek et al., 1997) and the Vp / Vs weighted average model (right). The Vp / Vs model profile is parallel to $9 \mathrm{HR} / 91$ and passes through the focal zone (profile C-C' in Fig. 1). Only areas constrained by the data are shown. Dashed lines show the layer exhibiting low Vp/Vs values, black circle shows the location of the 2008 swarm, red circles show past earthquake hypocentres (1991-1994) and yellow star shows the 1994 swarm centroid. Crust Units: G - granites, M - metasediments and metabasites, CU - crustal units with no surface reference, F - Fichtelgebirge and Erzgebirge crystalline unit. Geological profile (left) modified from Weise et al. (2001).

granites. However, it should be noted that earthquakes occurring on the northern section of the Nový Kostel fault plane (mainly inactive during the 2008 swarm) tend to occur at overall shallower depths (Fischer et al., 2010), such as the 1991-1994 hypocentres. We suggest that the transition from low to high Vp / Vs values denotes the base of the Fichtelgebirge granitic complex, and that it bounds the seismic activity to certain depths. Furthermore, the granitic intrusion may be a boundary blocking uprising magmatic fluids.

To investigate the possibility of the Fichtelgebirge granitic complex acting as a rupture boundary and possibly even a fluid trap, we calculate the brittleness index (Rickman et al., 2008) for the focal zone and overlaying layer. The brittleness index is a relative measure of the ease with which a material will fracture, calculated from its Poisson ratio and Young's modulus. A low index value indicates that a rock is resistant to fracturing. Assuming a uniform density within the focal zone and for the overlaying layer, we find that the brittleness index for the overlaying layer (36.41) is indeed lower than the index for the focal zone (41.94). The lack of seismic activity within this layer confirms its lower brittleness and resistance to fracturing. In addition to its lower brittleness, the Fichtelgebirge granitic complex may also have a lower porosity and/or permeability. As the upper mantle-derived fluids migrate towards the surface, they are trapped below this layer, the pore pressure increases and causes changes to the local stress field, facilitating slip-along pre-existing fractures or even allowing new fractures to form. Since the underlying rock is more brittle, the fractures preferentially occur there. The fluids migrate along the base of the Fichtelgebirge granitic complex, which results in the observed trend of shallower foci towards the end of the swarm period, and the shallower seismic activity to the north. The newly formed cracks provide new pathways for fluids. As the pore pressure decreases, the cracks and fractures close and the system returns to the initial conditions. This cycle of pore pressure increase and decrease may explain the periodic nature of the swarm seismicity in Nový Kostel.

A recently published study by Růžek and Horálek (2013) presented $P$-wave and $S$-wave velocity tomography models for the West Bohemia area. These models were further interpreted to provide Poisson's ratio, bulk modulus and Vp/ Vs models for the region. These models cannot be directly compared to the $P$-wave velocity or the $\mathrm{Vp} / \mathrm{Vs}$ WAM model presented here due to significant differences in resolution. According to Růžek and Horálek (2013), their models can resolve structures with a minimum size of $15 \mathrm{~km}$ laterally and $6 \mathrm{~km}$ vertically. The entire resolved area of our model is only slightly larger than these dimensions. Our synthetic tests show that the resolved area in our model can reliably image structures which extend in the order of $2-3 \mathrm{~km}$ laterally and $2 \mathrm{~km}$ vertically. Our interpretation is based on these fine-scale structures. In order to compare the models in a general sense, we analysed the images of the $\mathrm{Vp} / \mathrm{Vs}$ ratio depth slices provided by Růžek and Horálek (2013) as supplementary data. These images show an increase in $\mathrm{Vp} / \mathrm{Vs}$ near Nový Kostel. However, the colour scale does not allow for a precise comparison of the values. For this reason, we look to- 
wards the average $\mathrm{Vp} / \mathrm{Vs}$ values calculated directly from the average $P$-wave and $S$-wave velocity (digitized from their Fig. 7). It is evident that the average $\mathrm{Vp} / \mathrm{Vs}$ values are overall greater than ours, but they show a similar trend towards higher values with depth. Finally, the authors also note that the Poisson's ratio at $3 \mathrm{~km}$ below station NKC is low and thus shows a tendency towards increased brittleness. This contradicts our interpretation of low brittleness in the shallow areas and higher brittleness deeper, and within, the focal zone. However, since the depth commented on is not resolved in our analysis, we therefore cannot exclude this interpretation.

\section{Conclusions}

Past studies of the Nový Kostel Seismic Zone have indicated that fluids may be an important component of the swarm cycle. This hypothesis is addressed here by analysing the first detailed Vp / Vs model of the focal zone. The results of this study can be summarized by the following points:

- The Nový Kostel focal zone is characterized by high $\mathrm{Vp} /$ Vs values which concentrate along the 2008 swarm principal fault plane.

- A layer of low Vp / Vs directly overlays the fault zone.

- Earthquakes in this swarm only occur below $7 \mathrm{~km}$ depth, which correlates with the boundary between the low and high $\mathrm{Vp} / \mathrm{Vs}$ regions.

- The low Vp / Vs layer correlates to modelled estimates of the base of the Fichtelgebirge granitic complex in this area.

- The high Vp / Vs region correlates with the 2008 swarm seismicity.

- A comparison of the brittleness index for the metamorphic and granite units indicates that fractures will preferentially occur below the Fichtelgebirge granites. This is confirmed by the earthquake source locations.

- The low brittleness index of the overlaying layer indicates that it may bound the seismicity to certain depths and may also act as a fluid trap.

From these results, we hypothesize that the layer of low $\mathrm{Vp} / \mathrm{Vs}$ marks the upper boundary of the seismogenic zone and may also block uprising fluids. Over time, the pore pressure increases and the focal zone preferentially fractures due to its higher brittleness.

Given the large number of earthquakes recorded in the 2008 swarm, a follow-up study using the full event catalogue and 4-D tomography may image changes in the velocity structure throughout the proposed cycle. Also, an analysis of other well-documented swarms will further illuminate the structures within the Nový Kostel Seismic Zone and the role of fluids in the swarm activity.

\section{The Supplement related to this article is available online at doi:10.5194/se-5-863-2014-supplement.}

Acknowledgements. This study was funded through the European Community's FP7 Consortium Project AIM "Advanced Industrial Microseismic Monitoring”, Grant Agreement no. 230669 and by the Grant Agency of the Czech Republic, Grant no. 210/12/1491. We thank J. Horálek, T. Fischer, A. Boušková and the WEBNET group for providing the earthquake travel times and locations. V. Babuška, J. Plomerová, P. Hrubcová, W. Geissler, S. Buske, S. Shapiro and C. Langenbruch are thanked for the stimulating discussions. D. Kuehn, E. Korger and an anonymous reviewer are thanked for their insightful reviews which improved the quality of this manuscript.

Edited by: W. Geissler

\section{References}

Agostinetti, N. P. and Chiarabba, C.: Seismic structure beneath Mt Vesuvius from receiver function analysis and local earthquake tomography: evidences for location and geometry of the magma chamber, Geophys. J. Int., 175, 1298-1308, 2008.

Bankwitz, P., Schneider, G., Kämpf, H., and Bankwitz, E.: Structural characteristics of epicentral areas in Central Europe: study case Cheb Basin (Czech Republic), J. Geodynam., 35, 5-32, 2003.

Bouchaala, F., Vavryčuk, V., and Fischer, T.: Accuracy of the master-event and double-difference locations: synthetic tests and application to seismicity in West Bohemia, Czech Republic, J. Seismol., 17, 841-859, 2013.

Bräuer, K., Kämpf, H., Niedermann, S., and Strauch, G.: Evidence for ascending upper mantle-derived melt beneath the Cheb basin, central Europe, Geophys. Res. Lett., 32, L08303, doi:10.1029/2004GL022205, 2005.

Calò, M., Dorbath, C., Cornet, F., and Cuenot, N.: Large-scale aseismic motion identified through 4-D P-wave tomography, Geophys. J. Int., 186, 1295-1314, 2011.

Calò, M., Dorbath, C., Luzio, D., Rotolo, S. G., and D’Anna, G.: Seismic velocity structures of southern Italy from tomographic imaging of the Ionian slab and petrological inferences, Geophys. J. Int., 191, 751-764, 2012.

Fischer, T., Horálek, J., Michálek, J., and Boušková, A.: The 2008 West Bohemia earthquake swarm in the light of the WEBNET network, J. Seismol., 14, 665-682, 2010.

Fischer, T., Horálek, J., Hrubcová, P., Vavryčuk, V., Bräuer, K., and Kämpf, H.: Intra-continental earthquake swarms in WestBohemia and Vogtland: a review, Tectonophysics, 611, 1-27, 2014.

Geissler, W. H., Kämpf, H., Kind, R., Bräuer, K., Klinge, K., Plenefisch, T., Horálek, J., Zedník, J., and Nehybka, V.: Seismic structure and location of a $\mathrm{CO}_{2}$ source in the upper mantle of the western Eger (Ohře) rift, central Europe, Tectonics, 24, TC5001, doi:10.1029/2004TC001672, 2005. 
Hainzl, S., Fischer, T., and Dahm, T.: Seismicity-based estimation of the driving fluid pressure in the case of swarm activity in Western Bohemia, Geophys. J. Int., 191, 271-281, 2012.

Hecht, L., Vigneresse J. L., and Morteani, G.: Constraints on the origin of zonation of the granite complexes in the Fichtelgebirge (Germany and Czech Republic): evidence from a gravity and geochemical study, Geol. Rundsch., 86, S93-S109, 1997.

Heinicke, J., Fischer T., Gaupp, R., Götze, J., Koch, U., Konietzky, H., and Stanek, K.-P.: Hydrothermal alteration as a trigger mechanism for earthquake swarms: the Vogtland/NW Bohemia region as a case study, Geophys. J. Int., 178, 1-13, 2009.

Herrmann, R. B.: FASTHYPO - a hypocenter location program, Earthquake Notes, 50, 25-37, 1979.

Hrubcová, P., Sroda, P., Špičák, A., Guterch, A., Grad, M., Keller, G. R., Brueckl, E., and Thybo, H.: Crustal and uppermost mantle structure of the Bohemian Massif based on CELEBRATION 2000 data, J. Geophys. Res., 110, B11305, doi:10.1029/2004JB003080, 2005.

Hrubcová, P., Vavryčuk, V., Boušková, A., and Horálek, J.: Moho depth determination from waveforms of microearthquakes in the West Bohemia/Vogtland swarm area, J. Geophys. Res., 118, 120137, 2013.

Husen, S. and Kissling, E.: Postseismic fluid flow after the large subduction earthquake of Antofagasta, Chile, Geology, 29, 847850, 2001.

Ito, H., De Vilbiss, J., and Nur, A.: Compressional and shear waves in saturated rock during water-steam transition, J. Geophys. Res., 89, 4731-4735, 1979.

Kissling, E., Ellsworth, W. L., Eberhart-Phillips, D., and Kradolver, U.: Initial reference models in local earthquake tomography, J. Geophys. Res., 99, 19635-19646, 1994.

Málek, J., Horálek, J., and Janský, J.: One-dimensional qP-wave velocity model of the upper crust for the West Bohemia/Vogtland earthquake swarm region, Stud. Geophys. Geod., 49, 501-524, 2001.

McLaren, M. K., Hardebeck, J. L., van der Elst, N., Unruh, J. R., Bawden, G. W., and Blair, J. L.: Complex faulting associated with the 22 December 2003 Mw 6.5 San Simeon, California, earthquake, aftershocks, and postseismic surface deformation, Bull. Seis. Soc Am., 98, 1659-1680, 2008.

Mlčoch, B. and Skácelová, Z.: Digital elevation model of the crystalline basement of the Cheb and Sokolov Basin areas (Western Bohemia, central Europe), Z. Geol. Wiss., 3, 145-152, 2009.

Nehybka, V. and Skácelová, Z.: Seismological study of the Kraslice/Vogtland-Oberpfalz region, in: Geological Model of Western Bohemia in Relation to Deep Borehole KTB in the FGR, edited by: Vrána, S. and Štrědrá, V., Czech Geological Survey, Prague, J. Geol. Sci. Ser. Geol., 47, 186-190, 1997.

Peterek, A., Reuther, C. D., and Schunk, R.: Neotectonic evolution of the Cheb Basin (Northwestern Bohemia, Czech Republic) and its implications for the late Pliocene to Recent crustal deformation in the western part of the Eger Rift, Z. Geol. Wiss., 39, 335$365,2011$.

Popp, T. and Kern, H.: The influence of dry and water saturated cracks on seismic velocities of crustal rocks - A comparison of experimental data with theoretical model, Surv. Geophys., 15, 443-465, 1994.
Rickman, R., Mullen, M., Petre, E., Greiser, B., and Kundert, D.: A practical use of shale petrophysics for stimulation design optimization: all shale plays are not clones of the Barnett shale, 2008 SPE Annual Technical Conference and Exhibition, Denver, Colorado, USA, 21-24 September 2008, SPE 115258, 2008.

Růžek, B. and Horálek, J.: Three-dimensional seismic velocity model of the West Bohemia/Vogtland seismoactive region, Geophys. J. Int., 195, 1251-1266, 2013.

Růžek, B., Hrubcová, P., Novotný, M., Špičák, A., and Karousová, O.: Inversion of travel times obtained during active seismic refraction experiments CELEBRATION 2000, ALP 2002 and SUDETES 2003, Stud. Geophys. Geod., 51, 141-164, 2007.

Scarfi, L., Giampiccolo, E., Musumeci, C., Patane, D., and Zhang, H.: New insights on 3-D crustal structure in southeastern Sicily (Italy) and tectonic implications from an adaptive mesh seismic tomography, Phys. Earth Planet. Int., 161, 74- 85, 2007.

Špičák, A. and Horálek, J.: Possible role of fluids in the process of earthquake swarm generation in the West Bohemia/Vogtland seismoactive region, Tectonophysics, 336, 151-161, 2001.

Švancara, J., Haviŕ, J., and Conrad, W.: Derived gravity field of the seismogenic upper crust of SE Germany and West Bohemia and its comparison with seismicity, Stud. Geophys. Geod., 52, 567588, 2008.

Tomek, Č., Dvořáková, V., and Vrána, S.: Geological interpretation of the 9HR and 503M seismic profiles in Western Bohemia, Vrána, S. and Štrědrá, V., Czech Geological Survey, Prague, J. Geol. Sci. Ser. Geol., 47, 43-50, 1997.

Toomey, D. R. and Foulger, G. R.: Tomographic inversion of local earthquake data from the Hengill-Grensdalur central volcano complex, Iceland, J. Geophys. Res., 94, 17497-17510, 1989.

Um, J. and Thurber, C.: A fast algorithm for two-point seismic ray tracing, Bull. Seis. Soc. Am., 77, 3, 972-986, 1987.

Vavryčuk, V.: Non-double-couple earthquakes of January 1997 in West Bohemia, Czech Republic: Evidence of tensile faulting, Geophys. J. Int., 149, 364-373, 2002.

Vavryčuk, V.: Principal earthquakes: Theory and observations for the 2008 West Bohemia swarm, Earth Planet. Sci. Lett., 305, 290-296, 2011.

Vavryčuk, V., Bouchaala, F, and Fischer, T.: High-resolution fault image from accurate locations and focal mechanisms of the 2008 swarm earthquakes in West Bohemia, Czech Republic, Tectonophysics, 590, 189-195, 2013.

Waldhauser, F. and Ellsworth, W. L.: A double-difference earthquake location algorithm: method and application to the Hayward fault, Bull. Seism. Soc. Am., 90, 1353-1368, 2000.

Weise, S. M., Bräuer, K., Kämpf, H., Strauch, G., and Koch, U.: Transport of mantle volatiles through the crust traced by seismically released fluids: a natural experiment in the earthquake swarm area Vogtland/NW Bohemia, Central Europe, Tectonophysics, 336, 137-150, 2001.

Zhang, H. and Thurber, C. H.: Double-difference tomography: the method and its application to the Hayward fault, California, Bull. Seism. Soc. Am., 93, 1175-1189, 2003.

Zhang, H., Sarkar, S. Toksöz, M. N., Kueli, H. S., and Al-Kindy, F.: Passive seismic tomography using induced seismicity at a petroleum field in Oman, Geophysics, 74, WCB57-WCB69, 2009. 